\title{
Decrease of external skeletal robustness (Frame Index) between two cohorts of school children living in Puerto Madryn, Argentina at the beginning of the $21^{\text {st }}$ century
}

\author{
Bárbara Navazo ${ }^{1, *}$, Evelia Oyhenart ${ }^{1}$, Silvia Dahinten ${ }^{2,3}$, Rebekka Mumm $^{4}$ and \\ Christiane Scheffler ${ }^{4}$
}

1 Laboratorio de Investigaciones en Ontogenia y Adaptación (LINOA). Facultad de Ciencias Naturales y Museo (FCNyM), Universidad Nacional de La Plata (UNLP). Argentina

2 Instituto de Diversidad y Evolución Austral (IDEAus), CENPAT-CONICET

3 Facultad de Ciencias Naturales. Universidad Nacional de la Patagonia San Juan Bosco (UNPSJB), sede Puerto Madryn. Argentina

4 University of Potsdam, Institute of Biochemistry and Biology, Human Biology, Potsdam, Germany

* Corresponding author: barnavazo@gmail.com; bnavazo@fcnym.unlp.edu.ar

Bárbara Navazo ORCID: 0000-0001-8120-0597

Evelia Oyhenart ORCID: 0000-0003-1331-7368

Silvia Dahinten ORCID: 0000-0002-9969-7674

Rebekka Mumm ORCID: 0000-0001-9081-0899

Christiane Scheffler ORCID: 0000-0003-1954-7578

With 2 figures and 2 tables

\begin{abstract}
Background: It has been shown that modern life style with reduced physical activity can lead to lower bone accumulation. Also a decline trend in external skeletal robustness in children and young adolescents, measured by the Frame Index (FI), seems to have a parallel trend with the increase in overweight and obesity. Based on these findings we estimate that likely, the FI should be changed after a decade in the Argentinean population as well as in others population of the world. Thereby, the aim of the present study was to describe, using the FI, the pattern of external skeletal robustness in school children aged 6-14 years from two cohorts of Argentina (Puerto Madryn, Chubut) and to compare them with the European reference (Czech Republic, Germany, Poland and Russia). Methods: Elbow breadth and height of Puerto Madryn school children were collected in two cross-sectional studies conducted between 2001-2006 (cohort $1=\mathrm{C} 1$ ) and 20142016 (cohort 2 = C2). Percentiles (P) values, for males and females, from C1 and C2 were calculated combining the LMSmethod and its extension. A t-test has been used to compare, by age and sex, the FI values between the Argentinean cohorts and the European reference (ER). Then, in order to know the percentage of the variation of the percentiles values between cohorts, as well as with ER, percent differences between means (PDM\%) were employed. Results: FI from Argentinean cohorts differed significantly from ER. Even more, C2 was not only smaller than ER, but also than C1. In males, C1-C2 showed significant differences at 6-8, 11 and 12 years and in females at all ages. Then, respect to ER each Argentinean cohort showed significant differences in males of $\mathrm{C} 1$ at $6,12-14$ years and in females at 6 and 11-14 years; and of C2, in both sexes, from 6 to 14 years. The PDM\% values for elbow breadth of male were negative in ER-C1 in all percentiles analyzed; in ER-C2 positive (P3 and P50) and negative (P97) and C1-C2 recorded positive values. In females, elbow breadth showed negative values for ER-C1 (P50 and P97), and positive for the remaining values. Finally, height registered, in both sexes, negative values in ER-C1 (except P97 in females), ER-C2 and C1-C2. Conclusions: After ten years of the first study carried on in Puerto Madryn, school children show a negative trend in the external skeletal robustness. Additionally, the children of both Argentinean cohorts have lower values compared to the European reference, and mainly the actual cohort. This situation would be explained, in part, by the progressive increase over time of overweight and obesity as consequence, among others, of the change in the quantity and/or quality of the food that children have access to and with the physical activity they do at school and outside.
\end{abstract}

Keywords: elbow breadth; height; skeletal robustness; school children; Argentina 


\section{Introduction}

Modern industrialization has changed the way of life, interests and nutrition of children globally. These changes could have effects on their health and body composition, so detected deficiencies during childhood could be useful to develop prevention or intervention programs that can be implemented (Rietsch 2013).

Even though historically a fat child meant a healthy child, one who was likely to survive the rigors of undernourishment and infection, the excessive fatness has arguably become the primary childhood health problem in different parts of the world (Ebbeling et al. 2002). According to the Pan-American Health Organization, obesity in childhood and adolescence has reached epidemic proportions in the Americas region (PAHO 2014). In Argentina, a decade ago, Oyhenart et al. (2008) identified contrasting regional differences in the prevalence of excess of weight in school children from different provinces of the country. The results obtained by the authors indicated that the highest prevalence of overweight and obesity was recorded in the southern provinces. As an example, the city of Puerto Madryn located in the south (Patagonian region), showed in the period 2003-2005 the highest prevalence of overweight $(21.2 \%)$ and obesity $(5.5 \%)$ and the lowest of stunting (7.3\%) from the Argentinean population (Oyhenart et al. 2008). Ten years later, Navazo et al. (2018) analyzed the variation between two cohorts of school children from different neighborhoods of Puerto Madryn and observed that the prevalence of stunting remained or decreased, while those of obesity increased.

A common reason for overweight and obesity, besides a genetic component, is a malfunctioning balance of physical activity and nutritional intake (Dehghan et al. 2005; Scheffler 2011; Kar et al. 2014). Among the most important factors that promote weight gain and obesity are: high consumption of products of low nutritional value and high content of sugar, fat and salt, frequent intake of sugary drinks and insufficient physical activity (PAHO 2014).

Usually for quantifying overweight and obesity the Body Mass Index (BMI) is used. This index only describes the proportion of body weight (kilograms) and body height $\left(\right.$ metres $^{2}$ ) because it is a quotient of both, but it does not evaluate other things as body composition in detail, measures of skeletal robustness and specific estimates of percentage body fat (Scheffler 2011). Approximately thirty years ago, Frisancho (1990) proposed the Frame Index as a parameter for calculating body composition (Frisancho \& Flegel 1983). This index is associated with relative skeletal mass on body composition and has been used as a measurement of external skeletal robustness in both, current and past populations (Rietsch et al. 2013a; Scheffler 2011; Rietsch et al. 2013b; Scheffler 2013; Jasch et al. 2018). Because of the age-related changes of body weight and height of males and females, this method is the classical approach of frame size estimation with the objective of robustness (Frisancho 1990; Rietsch et al. 2013a).

In relation with the increment of the excess of weight's prevalence in childhood and/or youth, some authors provided evidences about a decline trend in external skeletal robustness in school children and young adolescents as a parallel trend to the increase in overweight and obesity (Scheffler 2011; Rietsch et al. 2013a; Rietsch et al. 2013b; Scheffler \& Hermanussen 2014; Musálek et al. 2018). Even though there is a huge amount of evidence about the increase of excess of weight in childhood all around the world (Wang \& Lobstein 2006; de Onis et al. 2010; Malik et al. 2013; Arroyo-Johnson \& Mincey 2016), the information about the external skeletal robustness is scarce. Two years ago, Mumm et al. (2018) published the first reference percentiles for Frame Index (FI) from European children and adolescents (ER). The ER data belong to different countries, such as: Czech Republic (Sedlak et al. 2015); Germany (Schilitz 2001; Kamtsiuris et al. 2007; Scheffler et al. 2007; Schüler 2009; Rietsch et al. 2013a; Hesse et al. 2016); Poland (Gomula et al. 2015; Nowak-Szczepanska et al. 2016; Suder et al. 2017) and Russia (Rietsch et al. 2013b).

In Argentina, until now, most of the information available from school children was centralized in the nutritional status and others aspect such as body composition (Oyhenart et al. 2007; Dahinten et al. 2011; Garraza et al. 2014; Cordero \& Cesani 2018). Nevertheless, the study of the skeletal robustness was not included. It was then, that we considered necessary to estimate that the FI could have been changed after a decade in the Argentinean and other populations. Thereby, the aim of the present study was to describe, using the FI, the pattern of external skeletal robustness in school children aged 6-14 years from two cohorts of Argentina (Puerto Madryn, Chubut) and to compare them with the European reference (Mumm et al. 2018).

\section{Material and methods}

\section{Sample}

In two cross-sectional studies conducted between the years 2001-2006 (cohort $1=\mathrm{C} 1$ ) and 2014-2016 (cohort $2=\mathrm{C} 2$ ), males and females aged from 6-14 years old were examined (Table 1). The anthropometric assessment of both cohorts was performed in the same schools located in different neighborhoods of the city of Puerto Madryn (province of Chubut, Argentina, $42^{\circ} 46^{\prime} 23^{\prime \prime} \mathrm{S} 65^{\circ} 02^{\prime} 12^{\prime \prime} \mathrm{W}$ ).

\section{Anthropometric measurements}

All anthropometric measurements were made using standardized equipment and according to the "Anthropometric Standardization Reference Manual" by Lohman et al. (1988). The variables considered were: height $(\mathrm{cm})$ and elbow breadth $(\mathrm{mm})$ and the Frame Index of skeletal robust- 
Table 1. Sample composition.

\begin{tabular}{|c|c|c|c|c|}
\hline \multirow{3}{*}{ Age (years) } & \multicolumn{4}{|c|}{ Cohort } \\
\hline & \multicolumn{2}{|c|}{1} & \multicolumn{2}{|c|}{2} \\
\hline & Males & Females & Males & Females \\
\hline $6.00-6.99$ & 194 & 152 & 143 & 140 \\
\hline $7.00-7.99$ & 213 & 159 & 160 & 171 \\
\hline $8.00-8.99$ & 197 & 203 & 158 & 186 \\
\hline $9.00-9.99$ & 184 & 208 & 155 & 212 \\
\hline $10.00-10.99$ & 142 & 162 & 143 & 166 \\
\hline $11.00-11.99$ & 175 & 157 & 168 & 177 \\
\hline $12.00-12.99$ & 168 & 186 & 172 & 150 \\
\hline $13.00-13.99$ & 182 & 152 & 128 & 113 \\
\hline $14.00-14.99$ & 144 & 132 & 102 & 90 \\
\hline All & 1599 & 1511 & 1329 & 1405 \\
\hline
\end{tabular}

ness was calculated as follows (Frisancho 1990): Frame Index $(\mathrm{FI})=[($ elbow breadth $/$ height $) \times 100]$.

For each age (in complete years) and sex, percentile values of FI were calculated.

\section{Ethics statement}

The investigation was carried out in accordance with the norms of the Nuremberg Code of 1947, the Universal Declaration of Human Rights of 1948, and the Helsinki Declaration of 1975 , as revised in 2000 . The research was approved by the Ministerio de Educación of the Chubut province, the Subsecretaria de Educación of the Puerto Madryn's city and the Comité de Bioética de la Escuela Latinoamericana de Bioética. The study was implemented on a voluntary basis with parents' permission, who signed a written informed consent and finally the children took part voluntarily.

\section{Statistics}

Following the propose of Mumm et al. (2018), percentiles (P) values (P3, P10, P25, P50, P75, P90 and P97) for males and females from Puerto Madryn school children were calculated combining the LMS-method by Cole (1990) and Cole \& Green (1992) and its extension by Rigby \& Stasinopoulos (2004; 2006). Then, C1 and C2 FI percentiles were compared with each other and with the percentiles of the ER (Mumm et al. 2018).

For graphical comparisons, mean values of P3, P50 and P97 were standardized by percent differences between means (PDM\%). This standardization method reduces any difference to a percent value which is not affected by the magnitude of the variables. PDM\% was calculated according to Guimarey et al. (2014): PDM\% $=100 *[(X 1-X 2) / X 1]$. For between-cohort comparisons: $\mathrm{X} 1=$ mean values of $\mathrm{C} 1$ and $\mathrm{X} 2=$ mean values of $\mathrm{C} 2$; and between reference and cohorts:
$\mathrm{X} 1=$ mean values of $\mathrm{ER}$ and $\mathrm{X} 2=$ mean values of $\mathrm{C} 1 ; \mathrm{X} 1=$ mean values of $\mathrm{ER}$ and $\mathrm{X} 2=$ mean values of $\mathrm{C} 2$.

A t-test has been used to compare the average FI values at a defined age in both sexes.

\section{Results}

Frame Index of Argentinean cohorts differed from ER (Fig. 1). Males from $\mathrm{C} 1$ showed a different trend respect to ER, depending on the age and the percentile analyzed. Until 8 years old, approximately, $\mathrm{C} 1$ values were above ER in P3, P10, P25, P50 and P75 and in the remaining ages they were below. Nevertheless, in P90 and in P97 the FI values were above ER until 12 years old and decreased afterwards. Conversely, C2 curves from P3 to P97 were below of ER in all ages (Fig. 1). In females, the FI values of $\mathrm{C} 1$ were higher than the ER and also C2, in all cases. Meanwhile, C2 was always below of the ER (Fig. 1).

When the PDM\% for elbow breadth was analyzed in males, the comparison between ER and C1 exhibited negative values in all percentiles; ER-C2 positive (P3 and P50) and negative (P97); and $\mathrm{C} 1-\mathrm{C} 2$ only positive values. In females, ER-C1 had negative values (P50 and P97), and positive for the remaining percentiles (Fig. 2). Finally, height in males had negative PDM\% values for ER-C1 and ER-C2 (P3, P50 and P97), and also for C1-C2 -all percentiles-. Similar results were observed in females with negative values in ER-C1 (excepted P97); ER-C2 and C1-C2 (Fig. 2).

Finally, according to the t-test, there were significant differences between $\mathrm{C} 1$ and $\mathrm{C} 2$ and also between each cohort and ER (Table 2). In relation to the age of the children, the comparison $\mathrm{C} 1-\mathrm{C} 2$ showed significant differences in males at 6-8, 11 and 12 years and in females at all ages. Comparing ER-C1 in males the differences were at $6,12-14$ years and in 

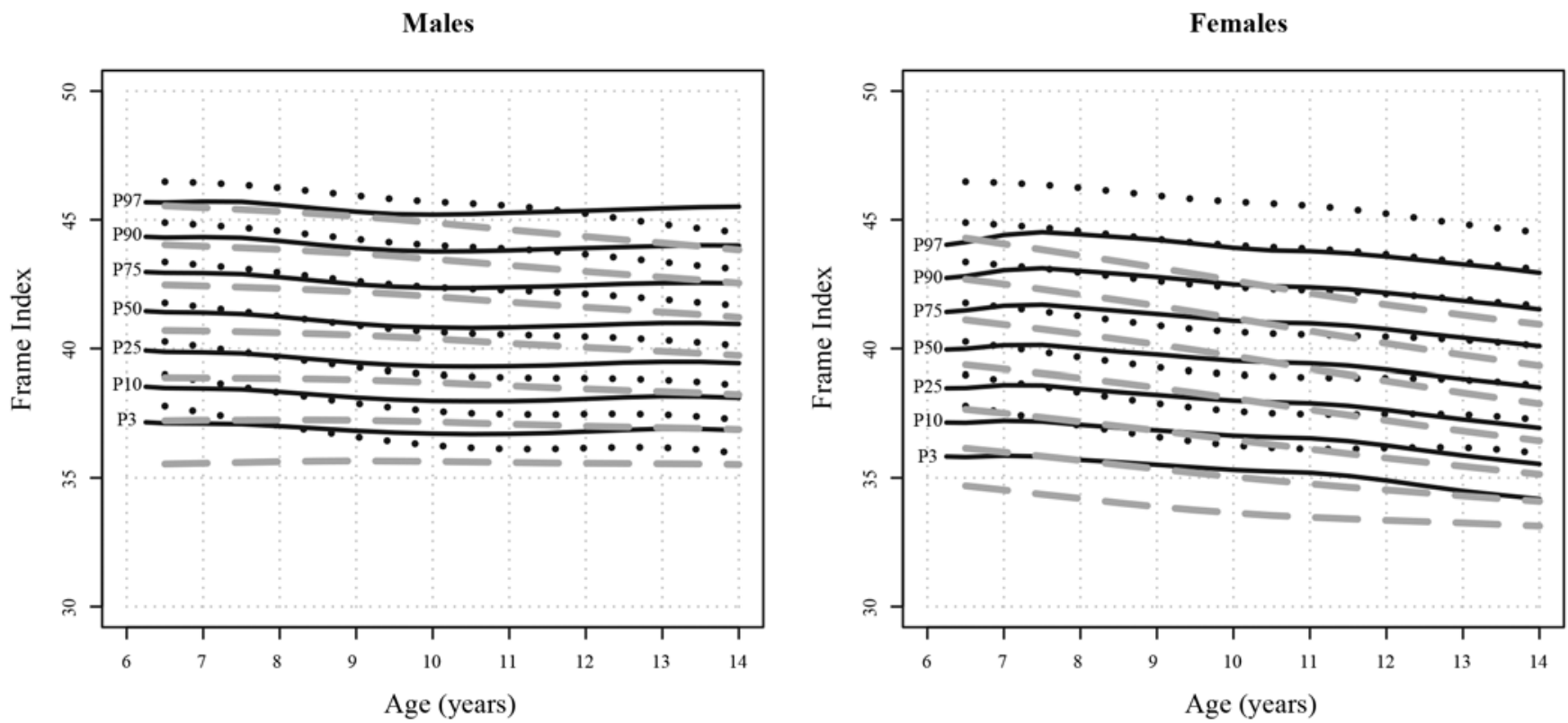

Fig. 1. Males and females aged 6 to 14 years. Percentiles of Frame Index $(\mathrm{mm} / \mathrm{cm})$ for European reference and cohort 1 and cohort 2 from Puerto Madryn (Argentina) calculated using the LMS-method. European reference _—, cohort 1 - - -, cohort 2 - - - .

Males
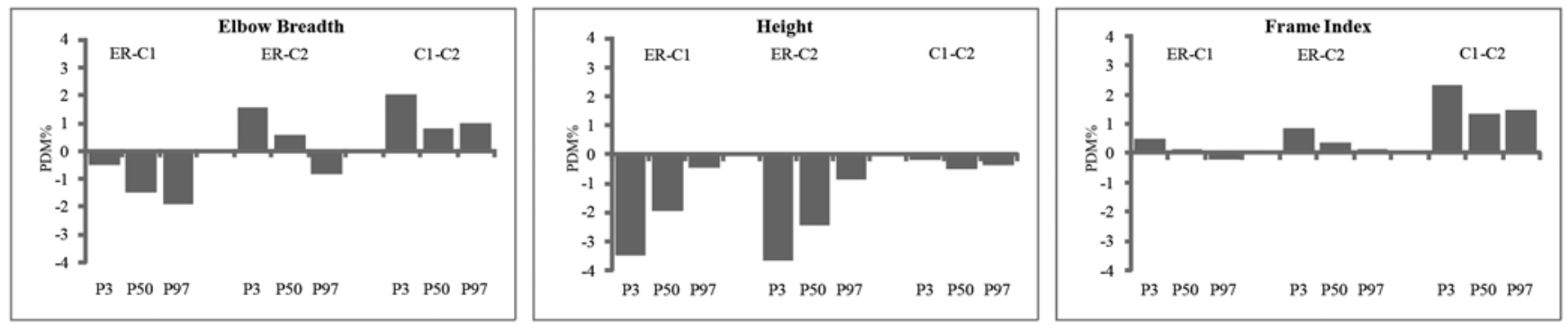

Females
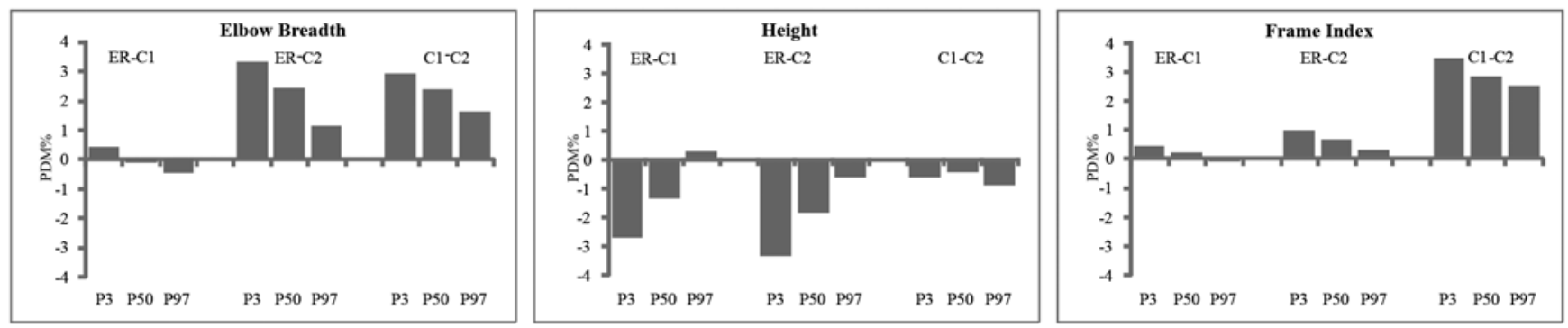

Fig. 2. Percent differences between means (PDM\%) of measured and calculated variables in males and females. Comparisons between cohorts (C1 and $\mathrm{C} 2$ ) and the European reference (ER). 
Table 2. Frame Index, comparison between Argentinean cohorts (C1 and $C 2)$ and European reference (ER). t-test.

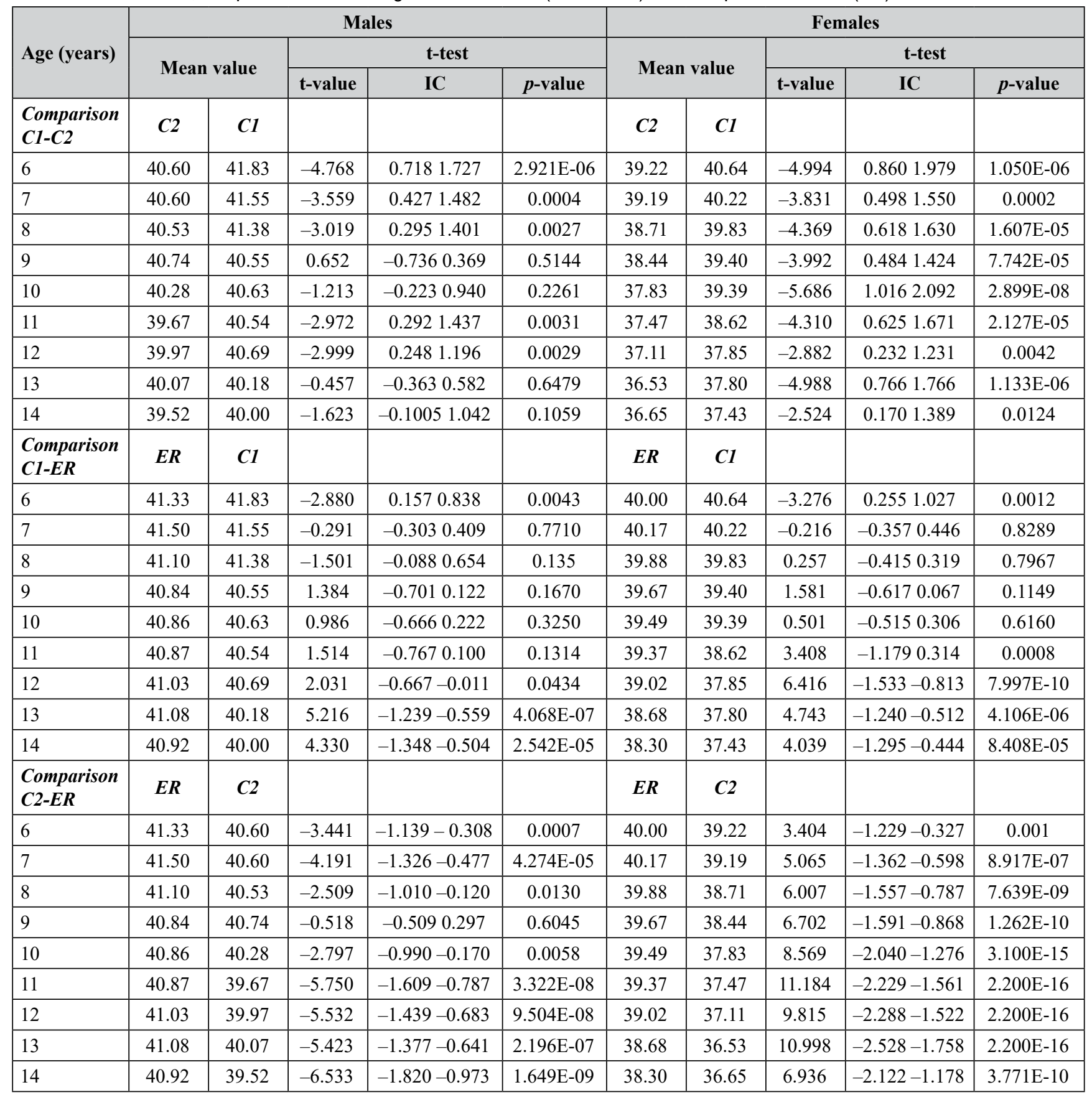

females at 6 and 11-14 years; and ER-C2 both sexes showed significant differences from 6 to 14 years (Table 2).

\section{Discussion}

As we hypothesized school children from Puerto Madryn registered a decline of FI between 2001 and 2016 (1\% in males and 3\% in females in P50). Also, the comparison of the European reference with both Argentinean cohorts was different, because Argentinean samples had minor values of FI, mainly the current cohort.

In order to analyze the modification in the development of the bone mass, authors as Matkovic et al. (1994) evidenced that almost $40 \%$ of the peak of the bone mass accumulates between pubertal stage 2 and 5. Then, Cameron \& Demerath (2002) proposed that more than $50 \%$ of the variance in the peak bone mass was accounted by genetic factors $(60-80 \%)$, and the rest (20-40\%) could be done to modifiable environmental factors such as nutrition and physical activity. More 
recently, Hermanussen et al. (2015) suggested that changes in physical exercise and psycho-social environment, even emotional, have left significant imprints in modern skeletal built during the last decades. In relationship to this, while Argentinean males and females were slightly taller than their European peers, the elbow breadth was bigger in $\mathrm{C} 1$ and smaller in C2. In addition, decrease of FI in boys and girls of both cohorts occurred independently the age and the percentile considered. According to Mumm et al. (2018), the decline of external skeletal robustness could be a consequence of a change of proportions during human development, since humans experience a greater linear growth, than a growth in skeletal breadth. Also, Scheffler \& Hermanussen (2018) mentioned that the relative FI decreases with the age and proposed that prior to the adolescent growth spurt, elbow breadth rapidly increases particularly in boys.

On the other hand, Klein et al. (2016) and Reinehr \& Roth (2019) proposed that overweight and obesity could accelerate the maturity velocity. These results added to those, found by Navazo et al. (2018), about that school children from C2 had higher ponderal excess than $\mathrm{C} 1$, could explain the FI decrease in $\mathrm{C} 2$.

Already in the 1990s, Slemenda et al. (1994) said that among the most important elements strongly associated with better skeletal mineralization were: daily calcium intake of 1 to $1.5 \mathrm{~g}$; regular weight-bearing physical activity; and normal sexual maturation and increases in body size (height, weight, muscle mass). Some years later, Janz et al. (2001) confirmed that physical activity influences bone accumulation, even before the modulating effects of the increase in sex hormones. The authors also stated that in active children, bone accumulation was greater and the risk of future osteoporotic fractures was lower.

Although usually a high FI corresponds with an increased in skeletal robustness (Rietsch et al. 2013a), different authors reported an opposite trend in this index and proposed an association between physical activity and relative elbow breadth (Scheffler 2011; Rietsch 2013; Rietsch et al. 2013a; Rietsch et al. 2013b; Scheffler \& Hermanussen 2014; Musálek et al. 2018). Some years ago, Scheffler (2011) suggested that the increase of overweight and the decrease of skeleton robustness in 6-12 years old children from Brandenburg (Germany) could be consequence of a reduced physical activity. Later, Rietsch et al. (2013a) provided evidence for a significant association between FI and step counts in samples of children from Berlin and Brandenburg (Germany) aged between 6 and 10 years old.

According to the WHO (2010), people from 5 to 17 years old should perform 60 minutes daily of physical activity (i.e. games, sports and physical education) and it would be convenient to incorporate at least three times a week of vigorous activities to contribute to strengthening muscles and bones. Nevertheless, studies like the "Encuesta Mundial de Salud Escolar" had shown that only $16.7 \%$ of Argentinean school children were physically active and that the level of inactivity has risen at older ages (EMSE 2012). According to the results of that survey, almost $50 \%$ of the pupils from 11 to 17 years old were sedentary and the percentage was significantly higher in females than in males $(52.8 \%$ vs 46.9\%) (Ponce et al. 2016). As expressed in the "Boletín del Observatorio de la Deuda Social Argentina" for the year $2013,53 \%$ of urban children and adolescents did not perform active outdoor games for a daily average of $40 \mathrm{~min}$ utes and $58 \%$ of that population did not perform structured physical activity in extracurricular hours. In the school environment, it was recorded that $48 \%$ of the students had less than two weekly physical education classes (Tuñon \& Laíño 2014). Specifically, in the province of Chubut, where Puerto Madryn is located, the time allocated in public schools for physical activity is 45 minutes weekly.

About the relationship between globalization and health, Sobal (2001) proposed that the increasing urbanization experienced in some countries could significantly change the pattern of food consumption and physical activity, enlarging the risks of obesity. Meanwhile, Pirgon \& Aslan (2015) suggested that an inadequate social environment and buildings not suitable for walking around push children into an inactive lifestyle. The rapid urbanization verified in Puerto Madryn from the decade of 1970s could constitute an impact factor in both, the nutritional status and level of activity of the population. In this regard, the adverse environmental conditions characteristic of the Patagonian region do not stimulate children and young people to perform outdoor activities, increasing the sedentary habits.

Another issue to consider is the association between Frame Index and percentage of body fat. About this, authors like Rietsch et al. (2013a) suggested that to burn the body fat mass further muscles are needed. Also, higher musculature influences the skeleton, and as a result, heavier children have to use more muscles for motion which impacts on bone structure and external skeletal robustness. Some years ago, Okubo et al. (2006) stated that the consumption of potassium, magnesium, calcium, vitamin $\mathrm{C}$, vitamin $\mathrm{D}$, and vitamin $\mathrm{K}$ was positively correlated with bone mass density. Meanwhile, Wosje et al. (2010) proposed that high intakes of darkgreen and deep-yellow vegetables and of processed-meat were related to high bone mass. In relation to this, it must be said that the city of Puerto Madryn is not a food producer and that is the reason why, like other cities in the province of Chubut, it is supplied by farmers from the Lower Valley of the Chubut River (Hughes \& Owen 2002; Secretaría de Ciencia y Tecnología de la Provincia de Chubut 2017). This regional supply is affected by the seasonality of the products and the competition of others from the north of the country (Secretaría de Ciencia y Tecnología de la Provincia de Chubut 2017). Thus, as in the city of Puerto Madryn, just a part of the food available (vegetables, beef, sheep and pigs) comes from the Lower Chubut River Valley (Albertoli et al. 2016), most part of the food consumed corresponds to food commercially processed, of higher density 
and a higher proportion of refined fats and carbohydrates (Dahinten et al. 2011).

\section{Conclusions}

The external skeletal robustness of the Puerto Madryn school children, after more than ten years, shows not only a negative trend but also a lower value compared to the European reference. This situation would be explained, in part, by the increase of ponderal excess as consequence of the nutrition as well as by its association with the physical activity carried out at school as well as outside. To reduce this trend, the focus should be on: 1) the development of programs aimed at incorporating good eating habits from an early age; 2 ) the promotion of daily physical activity both in schools and those outdoor recreational activities (in squares, parks, etc.), so that children and young people maximize bone mass and avoid future health problems such as osteoporosis or bone fractures.

Acknowledgements: The authors are grateful to the parents and children as well as the local authorities and educational staff from Puerto Madryn (Chubut, Argentina) and to Marcelo Gavirati and Delfina Palleres (IDEAus, CENPAT-CONICET) for their assistance and collaboration. Statistical analyses of data were conducted during the $3^{\text {rd }}$ International Summer School "Statistical Approaches to Developmental and Growth Data of Children" in Potsdam/Gülpe from the $15^{\text {th }}$ to $20^{\text {th }}$ of July in 2019 . The Summer school was supported by the Auxological Society (Gesellschaft für Auxologie), by the Society of Anthropology (Gesellschaft für Anthropologie). This study was also supported by the Agencia Nacional de Promoción Científica y Tecnológica (ANPCyT) (PICT OC-AR 99-4-7391, PICT OC-AR 1541 and 1145); Consejo Nacional de Investigaciones Científicas y Técnicas (CONICET) (PIP 2197) and Universidad de la Patagonia San Juan Bosco (SJB 10/C98); Universidad Nacional de La Plata (11/N 428).

\section{References}

Albertoli, S., Perez Cavenago, D., \& Pecorari, N. (2016). Investigación de la potencialidad económica y agroalimentaria del Valle Inferior del Río Chubut. Instituto Nacional de Tecnología Agropecuaria. INTA.

Arroyo-Johnson, C., \& Mincey, K. D. (2016). Obesity epidemiology worldwide. Gastroenterology Clinics of North America, 45(4), 571-579. https://doi.org/10.1016/j.gtc.2016.07.012 PMID:27837773

Cameron, N., \& Demerath, E. W. (2002). Critical periods in human growth and their relationship to diseases of aging. Yearbook of Physical Anthropology, 45(S35, Suppl 35), 159-184. https://doi. org/10.1002/ajpa.10183 PMID:12653312

Cole, T. J. (1990). The LMS method for constructing normalized growth standards. European Journal of Clinical Nutrition, 44(1), 45-60. PMID:2354692
Cole, T. J., \& Green, P. J. (1992). Smoothing reference centile curves: The LMS method and penalized likelihood. Statistics in Medicine, 11(10), 1305-1319. https://doi.org/10.1002/sim. 4780111005 PMID: 1518992

Cordero, M. L., \& Cesani, M. F. (2018). Desigualdades en el crecimiento infantil y la composición corporal de escolares urbanos y rurales de Tucumán (Argentina). Nutrición Clínica, Dietética Hospitalaria, 38(4), 123-130.

Dahinten, S. L., Castro, L. E., Zavatti, J. R., Forte, L. M., \& Oyhenart, E. E. (2011). Growth of school children in different urban environments in Argentina. Annals of Human Biology, 38(2), 219-227. https://doi.org/10.3109/03014460.2010.5159 49 PMID:20849249

Dehghan, M., Akhtar-Danesh, N., \& Merchant, A. T. (2005). Childhood obesity, prevalence and prevention. Nutrition Journal, 4(24), 24-33. https://doi.org/10.1186/1475-2891-4-24 PMID:16138930

de Onis, M., Blössner, M., \& Borghi, E. (2010). Global prevalence and trends of overweight and obesity among preschool children. The American Journal of Clinical Nutrition, 92(5), 1257-1264. https://doi.org/10.3945/ajcn.2010.29786 PMID:20861173

Ebbeling, C. B., Pawlak, D. B., \& Ludwig, D. S. (2002). Childhood obesity: Public-health crisis, common sense cure. Lancet, 360(9331), 473-482. https://doi.org/10.1016/S0140-6736(02) 09678-2 PMID: 12241736

EMSE (Encuesta Mundial de Salud Escolar). (2012). Estrategia nacional de prevención y control de enfermedades no transmisibles. Argentina: Organización Panamericana de la Salud/ Ministerio de Salud.

Frisancho, A. R. (1990). Anthropometric standards for the assessment of growth and nutritional status. Ann Arbor, Michigan: University of Michigan Press. https://doi.org/10.3998/mpub. 12198

Frisancho, A. R., \& Flegel, P. N. (1983). Elbow breadth as a measure of frame size for US males and females. The American Journal of Clinical Nutrition, 37(2), 311-314. https://doi. org/10.1093/ajcn/37.2.311 PMID:6823895

Garraza, M., Zonta, M. L., Oyhenart, E. E., \& Navone, G. T. (2014). Estado nutricional, composición corporal y enteroparasitosis en escolares del departamento de San Rafael, Mendoza, Argentina. Nutrición Clínica, Dietética Hospitalaria, 34(1), 31-40.

Gomula, A., Nowak-Szczepanska, N., Danel, D. P. \& Koziel, S. (2015). Overweight trends among Polish schoolchildren before and after the transition from communism to capitalism. Economics \& Human Biology, 19, 246-257. https://doi. org/10.1016/j.ehb.2015.09.002

Guimarey, L. M., Castro, L. E., Torres, M. F., Cesani, M. F., Luis, M. A., Quintero, F. A., \& Oyhenart, E. E. (2014). Secular changes in body size and body composition in schoolchildren from La Plata City (Argentina). Anthropologischer Anzeiger, 71(3), 287-301. https://doi.org/10.1127/0003-5548/2014/0364 PMID:25065121

Hermanussen, M., Scheffler, C., Groth, D., \& Aßmann, C. (2015). Height and skeletal morphology in relation to modern life style. Journal of Physiological Anthropology, 34(1), 41. https://doi. org/10.1186/s40101-015-0080-4 PMID:26642759

Hesse, V., Schnabel, O., Judis, E., Cammann, H., Hinkel, J., \& Weissenborn, J. (2016). Längsschnittstudie des aktuellen Wachstums 0- bis 6-jähriger deutscher Kinder: Teil 2. Monatsschrift Kinderheilkunde, 164(10), 892-912. https://doi. org/10.1007/s00112-016-0068-0 
Hughes, J. C. \& Owen, O. M. (2002). Trabajadores migrantes bolivianos en la horticultura argentina: transformación del paisaje rural en el valle inferior. Scripta Nova, Revista Electrónica de Geografia y Ciencias Sociales. http://www.ub.es/geocrit/sn/ sn119125.htm

Janz, K. F., Burns, T. L., Torner, J. C., Levy, S. M., Paulos, R., Willing, M. C., \& Warren, J. J. (2001). Physical activity and bone measures in young children: The Iowa bone development study. Pediatrics, 107(6), 1387-1393. https://doi.org/10.1542/ peds.107.6.1387 PMID:11389262

Jasch, I., Langer, A., Boley, M., Mumm, R., Riesenberg, M., Mann, R., \& Wahl, J. (2018). Osseous Frame Index calculations of the early medieval South-West Germany. Anthropologischer Anzeiger, 74(5), 431-443. https://doi.org/10.1127/anthranz/ 2018/0822 PMID:29762629

Kamtsiuris, P., Lange, M., \& Rosario, A. (2007). Der Kinderund Jugendgesundheitssurvey (KiGGS): Stichprobendesign, Response und Nonresponse-Analyse [The German Health Interview and Examination Survey for Children and Adolescents (KiGGS): Sample design, response and nonresponse analysis]. Bundesgesundheitsblatt, Gesundheitsforschung, Gesundheitsschutz, 50(5-6), 547-556. https://doi.org/10.1007/s00103-0070215-9 PMID: 17514438

Kar, S. S., Dube, R., \& Kar, S. S. (2014). Childhood obesity-an insight into preventive strategies. Avicenna Journal of Medicine, 4(4), 88-93. https://doi.org/10.4103/2231-0770.140653 PMID: 25298951

Klein, K. O., Newfield, R. S., \& Hassink, S. G. (2016). Bone maturation along the spectrum from normal weight to obesity: A complex interplay of sex, growth factors and weight gain. Journal of Pediatric Endocrinology \& Metabolism, 29(3), 311318. https://doi.org/10.1515/jpem-2015-0234 PMID:26565541

Lohman, T. G., Roche, A. F., \& Martorell, R. (1988). Anthropometric Standardization Reference Manual. Champaign, IL: Human Kinetics Books.

Malik, V. S., Willett, W. C., \& Hu, F. B. (2013). Global obesity: Trends, risk factors and policy implications. Nature Reviews. Endocrinology, 9(1), 13-27. https://doi.org/10.1038/nrendo. 2012.199 PMID:23165161

Matkovic, V., Jelic, T., Wardlaw, G. M., Ilich, J. Z., Goel, P. K., Wright, J. K., ... Heaney, R. P. (1994). Timing of peak bone mass in Caucasian females and its implication for the prevention of osteoporosis. Inference from a cross-sectional model. The Journal of Clinical Investigation, 93(2), 799-808. https://doi. org/10.1172/JCI117034 PMID:8113412

Mumm, R., Godina, E., Koziel, S., Musalek, M., Sedlak, P., Wittwer-Backofen, U., ... Scheffler, C. (2018). External skeletal robusticity of children and adolescents - European references from birth to adulthood and international comparisons. Anthropologischer Anzeiger, 74(5), 383-391. https://doi.org/ 10.1127/anthranz/2018/0826 PMID:29461563

Musálek, M., Pařízková, J., Godina, E., Bondareva, E., Kokštejn, J., Jírovec, J., \& Vokounová, Š. (2018). Poor skeletal robustness on lower extremities and weak lean mass development on upper arm and calf: Normal weight obesity in middle-school-aged children (9 to 12). Frontiers in Pediatrics, 6, 371. https://doi. org/10.3389/fped.2018.00371 PMID:30574472

Navazo, B., Dahinten, S. L., \& Oyhenart, E. E. (2018). Malnutrición y pobreza estructural. Comparación de dos cohortes de escolares de Puerto Madryn, Argentina. Revista de Salud Publica
(Bogota, Colombia), 20(1), 60-66. https://doi.org/10.15446/ rsap.v20n1.68576 PMID:30183886

Nowak-Szczepanska, N., Gomula, A., Ipsen, M. J. \& Koziel, S. (2016). Different effects of living conditions on the variation in BMI and height in children before the onset of puberty. European Journal of Clinical Nutrition 70, 662-666. https://doi.org/ 10.1038/ejen.2016.30

Okubo, H., Sasaki, S., Horiguchi, H., Oguma, E., Miyamoto, K., Hosoi, Y., ... Kayama, F. (2006). Dietary patterns associated with bone mineral density in premenopausal Japanese farmwomen. The American Journal of Clinical Nutrition, 83(5), 1185-1192. https://doi.org/10.1093/ajen/83.5.1185 PMID: 16685064

Oyhenart, E. E., Torres, M. F., Quintero, F. A., Luis, M. A., Cesani, M. F., Zucchi, M., \& Orden, A. B. (2007). Estado nutricional y composición corporal de niños pobres residentes en barrios periféricos de La Plata, Argentina. Revista Panamericana de Salud Pública, 22(3), 194-201. https://doi.org/10.1590/S102049892007000800006 PMID:18062854

Oyhenart, E. E., Dahinten, S. L., Alba, J. A., Alfaro, E. L., Bejarano, I. F., Cabrera, G. E., ... Zavatti, J. R. (2008). Estado nutricional infanto juvenil en seis provincias de Argentina: Variación regional. Revista Argentina de Antropología Biológica, 10(1), $1-62$.

PAHO (Panamerican Health Organization) (2014). Plan de acción para la prevención de la obesidad en la niñez y la adolescencia. https://www.paho.org/hq/dmdocuments/2015/Obesity-Plan-OfAction-Child-Spa-2015.pdf

Pirgon, Ö., \& Aslan, N. (2015). The role of urbanization in childhood obesity. Journal of Clinical Research in Pediatric Endocrinology, 7(3), 163-167. https://doi.org/10.4274/jcrpe. 1984 PMID:26831548

Ponce, M., Allemandi, L., Castronuovo, L., Tiscornia, V., Gutkowski, P. \& Schoj, V. (2016). Brechas sociales de la obesidad en la niñez y adolescencia: Análisis de la encuesta mundial de salud escolar (EMSE). Argentina: Fundación Interamericana del Corazón (FIC)/Fondo de las Naciones Unidas para la Infancia (UNICEF).

Reinehr, T., \& Roth, C. L. (2019). Is there a causal relationship between obesity and puberty? The Lancet. Child \& Adolescent Health, 3(1), 44-54. https://doi.org/10.1016/S2352-4642(18) 30306-7 PMID:30446301

Rietsch, K. (2013). Body composition especially external skeletal robustness in association with physical activity and recreation in pre-pubertal children: A national and international investigation. Doctoral Thesis.

Rietsch, K., Eccard, J. A., \& Scheffler, C. (2013a). Decreased external skeletal robustness due to reduced physical activity? American Journal of Human Biology, 25(3), 404-410. https:// doi.org/10.1002/ajhb.22389 PMID:23606229

Rietsch, K., Godina, E., \& Scheffler, C. (2013b). Decreased external skeletal robustness in schoolchildren-A global trend? Ten year comparison of Russian and German data. PLoS One, 8(7), e68195. https://doi.org/10.1371/journal.pone.0068195 PMID: 23935857

Rigby, R. A., \& Stasinopoulos, D. M. (2004). Smooth centile curves for skew and kurtotic data modelled using the Box-Cox power exponential distribution. Statistics in Medicine, 23(19), 30533076. https://doi.org/10.1002/sim.1861 PMID:15351960

Rigby, R. A., \& Stasinopoulos, D. M. (2006). Using the Box-Cox $\mathrm{t}$ distribution in GAMLSS to model skewness and kurtosis. 
Statistical Modelling, 6(3), 209-229. https://doi.org/10.1191/ 1471082X06st122oa

Scheffler, C. (2011). The change of skeletal robustness of 6-12 years old children in Brandenburg (Germany) - Comparison of body composition 1999-2009. Anthropologischer Anzeiger, 68(2), 153-165. https://doi.org/10.1127/0003-5548/2011/0095 PMID:21452680

Scheffler, C. (2013). Determining body composition in field studies. In M. Hermanussen (Ed.), Auxology. Studying Human Growth and Development (pp. 32-33). Stuttgart: Schweizerbart.

Scheffler, C., Ketelhut, K., \& Mohasseb, I. (2007). Does physical education modify the body composition? - Results of a longitudinal study of pre-school children. Anthropologischer Anzeiger, 65(2), 193-201. https://doi.org/10.1127/anthranz/65/2007/193 PMID: 17711151

Scheffler, C., \& Hermanussen, M. (2014). Is there an influence of modern life style on skeletal build? American Journal of Human Biology, 26(5), 590-597. https://doi.org/10.1002/ajhb.22561 PMID:24846748

Scheffler, C., \& Hermanussen, M. (2018). Growth in childhood and adolescence. The International Encyclopedia of Biological Anthropology. https://doi.org/10.1002/9781118584538.ieba0537

Schilitz, A. (2001). Körperliche Entwicklung und Körperzusammensetzung von Brandenburger Schulkindern im Geschlechter- und Altersgruppenvergleich. Berichte aus der Biologie. Aachen: Shaker.

Schüler, G. (2009). Potsdamer Längsschnittstudie: Beurteilung der körperlichen Entwicklung vom Kleinkindalter bis zum frühen Schulalter mit Hilfe von Somatometrie, Fotogrammetrie und Morphognose. Doctoral thesis.

Secretaría de Ciencia y Tecnología de la Provincia de Chubut. (2017). Perfil Productivo de Chubut. http://ciencia.chubut.gov. ar/wp-content/uploads/2017/07/PERFIL-PRODUCTIVOCHUBUT-v130517-compressed.pdf

Sedlak, P., Pařízková, J., Daniš, R., Dvořáková, H., \& Vignerová, J. (2015). Secular Changes of Adiposity and Motor Development in Czech Preschool Children: Lifestyle Changes in Fifty-Five Year Retrospective Study. BioMed Research International, 2015, 823841. https://doi.org/10.1155/2015/823841 PMID: 26380296
Slemenda, C. W., Reister, T. K., Hui, S. L., Miller, J. Z., Christian, J. C., \& Johnston, C. C., Jr. (1994). Influences on skeletal mineralization in children and adolescents: Evidence for varying effects of sexual maturation and physical activity. The Journal of Pediatrics, 125(2), 201-207. https://doi.org/10.1016/S00223476(94)70193-8 PMID:8040762

Sobal, J. (2001). Commentary: Globalization and the epidemiology of obesity. International Journal of Epidemiology, 30(5), 11361137. https://doi.org/10.1093/ije/30.5.1136 PMID:11689535

Suder, A., Gomula, A., \& Koziel, S. (2017). Central overweight and obesity in Polish schoolchildren aged 7-18 years: Secular changes of waist circumference between 1966 and 2012. European Journal of Pediatrics, 176(7), 909-916. https://doi. org/10.1007/s00431-017-2938-4 PMID:28540432

Tuñon, I., \& Laíño, F. (2014). Insuficiente actividad física en la infancia: niños, niñas y adolescentes entre 5 y 17 años en la Argentina urbana Serie del Bicentenario 2010-2016; boletín $\mathrm{n}^{\mathrm{o}} 2$. Observatorio de la Deuda Social Argentina. Barómetro de la Deuda Social de la Infancia. Universidad Católica Argentina.

Wang, Y., \& Lobstein, T. (2006). Worldwide trends in childhood overweight and obesity. International Journal of Pediatric Obesity; IJPO, 1(1), 11-25. https://doi.org/10.1080/174771606 00586747 PMID:17902211

WHO (2010). Recomendaciones mundiales sobre actividad fisica para la salud. https://apps.who.int/iris/bitstream/handle/10665/ 44441/9789243599977_spa.pdf;jsessionid=C1AA43134D0D4 2104300EE29DEFE208F?sequence $=1$

Wosje, K. S., Khoury, P. R., Claytor, R. P., Copeland, K. A., Hornung, R. W., Daniels, S. R., \& Kalkwarf, H. J. (2010). Dietary patterns associated with fat and bone mass in young children. The American Journal of Clinical Nutrition, 92(2), 294-303. https://doi.org/10.3945/ajen.2009.28925 PMID: 20519562

Manuscript received: 24 October 2019

Revisions requested: 24 November 2019

Revised version received: 17 March 2020

Accepted: 17 March 2020 